\title{
Negative Emotions Experienced by Polish English Teachers During COVID-19. A Qualitative Study Based on Diaries
}

\begin{abstract}
The aim of the article is to discuss the research results of the study conducted on English teachers' negative emotions experienced during COVID-19. In order to collect the data, 30 English teachers from secondary schools were asked to keep a diary for one semester and describe situations that aroused feelings of anxiety, anger, and loneliness. The study was of a qualitative nature, and it showed that most of the emotions that the English teachers experienced were associated with the lack of support from the government and their colleagues, and also with the uncertainty about the future.

Keywords: online education, negative emotions, English teacher, COVID-19
\end{abstract}

\section{Introduction}

Emotions have been proved to be very important in the process of reflection as people who experience events learn better when there is emotional involvement (Arnold, 2019; Swan \& Bailey, 2004). Nevertheless, "reflection is a complex cognitive and affective process which takes time and practice to develop and integrate into one's mind, heart and life" (Stanley 1999, p. 111). Taylor (2001, p. 219) and Weiss (2000, p. 45) claim that higher-level learning is the result of linking feelings with reason and that the process of reflection involves both rationality and intuition. In other words, emotions can be a catalyst for the process of reflection, as they stimulate further action. The spread of COVID-19 at the beginning of 2020 led to the closure of schools and universities worldwide and forced the transition to compulsory online learning. This process, which turned out to be very challenging for teachers and students, evoked many different emotions.

The article aims at discussing the research results of the study conducted on English teachers' negative emotions experienced during COVID-19. Thirty English teachers from secondary schools were asked to keep a diary for one semester and describe situations that aroused feelings of anxiety, anger, and loneliness. The

Katarzyna Papaja, Zakład Językoznawstwa Stosowanego, Instytut Języka Angielskiego, Wydział Filologiczny Uniwersytetu Śląskiego, ul. Gen. Stefana Grota-Roweckiego 5, 41-205 Sosnowiec, katarzyna.papaja@us.edu.pl, http://orcid.org/0000-0003-2808-443X 
collected data showed that most of the emotions that the English teachers experienced were associated with the lack of support from the government and their colleagues, and also with the uncertainty about the future.

\section{Teacher's emotions}

Emotions can be classified into positive emotions such as joy, satisfaction, pride, or love and negative ones such as anger, exhaustion, hopelessness, anxiety, shame, or boredom (Chen, Kaczmarek, \& Ohyama, 2020; Sutton \& Wheatley, 2003; Watson \& Clark, 1988). Emotions have been considered an essential part of teachers' professional lives, given that, teachers experience all of them depending on a variety of classroom and school situations.

Research into teachers' emotions has shown that they might be linked to students, their learning, teachers themselves, teaching, as well as educational policies, parents' expectations and relationships with other colleagues from school (Becker, Goetz, Morger, \& Ranellucci, 2014; Scott \& Sutton, 2019; Traxler \& Frenzel, 2015). Becker et al. (2014, p. 21) claim that teachers' positive emotions have a significant impact on students' engagement, motivation and enjoyment. Furthermore, Zembylas, Charalambous, C., \& Charalambous, P. (2014) prove that positive emotions "produce a better learning environment, which supports student learning and development" (p. 74). The teachers' negative emotions, on the other hand, are considered to have a negative influence on students' deeper level of cognitive learning approaches (van Uden, Ritzen, \& Pieters, 2014, p. 30) and are often referred to as "critical emotional filters" (Hargreaves, 2001, p. 1056; Yoo \& Carter, 2017, p. 40; Zembylas et al., 2014, p. 75). In the case of the impact of emotions on the teachers themselves, it was found that positive emotions cause more in-depth pedagogical thoughts, influence self-efficacy, vulnerability, and teacher well-being (Brigido, Borrachero, Bermejo, \& Mellado, 2013, p. 214; Mercer \& Gregersen, 2020, pp. 138-142; Neville, 2013, p. 20). In contrast, negative emotions discourage teachers' motivation and might lead to anxiety, burnout syndrome, and even depression (MacIntyre, Gregersen \& Mercer, 2020, p. 2; Yin, Huang, \& Wang, 2017, p. 921). Finally, several empirical studies show that positive emotions have a great impact on the relationship with colleagues and parents. Those teachers who experience positive emotions are more likely to adopt flexible and creative approaches and are more open-minded and friendly (Chen, 2016, p. 72; MacIntyre et al., 2019, p. 32; Sauders, 2013, p. 329). On the other hand, those who experience negative emotions tend to quarrel more with their colleagues and might display a negative attitude to parents (Becker et al., 2014, p. 22; Kitching, 2009, p. 150; Yao et al., 2015, p. 12510).

The findings by many researchers provide an insight into the importance of emotions teachers experience and contribute to the discussion concerning teacher well-being especially in times of a pandemic when teaching has become a greater challenge. 


\section{Online education during COVID-19}

There is no doubt that the COVID-19 pandemic has affected the process of education at all levels. Suddenly, the teachers had to create a completely new learning environment meeting the students' expectations, which was a great challenge bearing in mind that most educational institutions had not been prepared for it (Flores \& Gago, 2020). "The ongoing COVID-19 crisis has been and will continue to be, both a massive challenge and a learning experience for the global education community. Practically no one saw (or wanted to believe) something like this coming" (Tuominen \& Leponiemi, 2020, p. 7). This unexpected change led to many opportunities but also constraints. On the one hand, lockdown measures have forced educational institutions to exploit the possibilities of technology (Kaur, 2020, p. 416; Miller, MacLaren, \& Xu, 2020 p. 3; Rapanta, Botturi, Goodyear, Guàrdia, \& Koole, 2020, p. 4). On the other, this situation has also served to identify problems, weaknesses, and space for reflection, especially regarding digital literacy and innovation in education, assessment, and evaluation processes (Kaur, 2020, p. 416; Manzoor, 2020, p. 2).

It is widely known that online education has enormous potential for increasing access to broader knowledge and education across the world (Traxler, 2018). Furthermore, new technologies provide the students and the teachers with opportunities to learn and teach anywhere and anytime (Brown, 2017). What is more, online education allows them to set their own learning/teaching schedule and become more independent individuals (Dumford \& Miller, 2018, p. 453). On the other hand, one of the most often mentioned drawbacks in the literature is the lack of social interaction, which leads to the feeling of isolation both on the part of the teachers and the learners (Brown, 2017; Costley \& Lange, 2017; Hutt, 2017; Kruse, 2001). Moreover, the lack of physical interaction in the educational process might lead to many problems connected with communication, academic performance, or even mental and physical health (Kelly, Zakrajsek, \& PacanskyBrock, 2021, p. 14).

Confusion and stress for teachers have been identified by UNESCO (2020) as one of the consequences of school closures. Many teachers were left alone and had to cope with the new situation on their own (McCarthy, 2020). Furthermore, the uncertainty about how long this situation might last and the unpleasant emotions experienced during this period led to the prolonged feeling of stress (MacIntyre et al., 2020, p. 3). There are not many studies conducted during the COVID-19 pandemic among teachers, focusing on the emotions they experience. However, the recent data indicates that the topic is significant and needs a thorough investigation. Al Lily, Ismail, Abunasser, and Alhajhoj (2020, p. 12) reveal that the present pandemic situation caused teachers to suffer problems that are often related to a pandemic situation, such as anxiety, depression, domestic violence, and divorce, all of which restrict their ability to teach properly. Other 
data obtained from a study conducted in Spain shows that teachers experienced psychosomatic problems and exhaustion due to the workload connected with online teaching (Prado-Gascó, Gómez-Domínguez, Soto-Rubio, Díaz-Rodríguez, \& Navarro-Mateu, 2020). Moreover, it was indicated in the previous studies that working from home using modern technologies might create feelings of tension, anxiety, exhaustion, and decreased job satisfaction (Cuervo-Cazurra, Ciravegna, Melgarejo, \& Lopez, 2018; Krish, 2008; Nagrale, 2013). At this point, it is also worth mentioning that teaching, in general, is placed as one of the most stressful professions as it is prone to heavy workloads, unbalanced work-life integration, limited autonomy, time constraints, enormous administrative obligations, difficult relationships with colleagues and school leaders, role conflict/ambiguity, emotional labour, dread over losing control of the class, fear of evaluation, and low professional self-esteem, (Mercer \& Gregersen, 2020, p. 138). Bearing in mind all these stressful factors mentioned above and the COVID-19 pandemic situation, it is no wonder that the unpleasant work-related emotions associated with online education are becoming the topic of discussion among education professionals, policymakers, and researchers (Kim \& Asbury, 2020, p. 1063).

\section{The current research}

One of the main objectives of the current study was to investigate English teachers' negative emotions experienced during COVID-19. It should be clearly stated from the very outset, however, that the research to be reported in the following stages is of a descriptive-exploratory nature, and its goal is "to analyse the data as they are rather than to compare them to other data to see how similar they are" (van Lier, 1988, p. 2). Based on the literature review, I assumed that there is a need to investigate the negative emotions such as anxiety, anger, and loneliness since these emotions are the ones that teachers are often afraid to talk about. Therefore, the research questions were the following:

1) What are the factors that caused anxiety during online teaching in the COVID-19 pandemic?

2) What are the factors that caused anger during online teaching in the COVID-19 pandemic?

3) What are the factors that caused loneliness during online teaching in the COVID-19 pandemic?

\subsection{Research participants}

A total of 30 English teachers participated in the study; 28 females and 2 males. The basic demographic data concerning teaching experience and the type of school is presented in Table 1 below: 
Table 1. Participants' basic data

\begin{tabular}{|c|c|c|c|}
\cline { 2 - 4 } \multicolumn{2}{c|}{} & Frequency & Percentage \\
\hline \multirow{3}{*}{ Teaching experience } & $0-1$ year & 1 & 3,3 \\
\cline { 2 - 4 } & 2-4 years & 7 & 23,3 \\
\cline { 2 - 4 } & $5-10$ years & 12 & 40,0 \\
\cline { 2 - 4 } & 11-20 years & 5 & 16,6 \\
\cline { 2 - 4 } & more than 20 years & 5 & 16,6 \\
\hline \multirow{2}{*}{ Type of school } & Primary School & 15 & 50,0 \\
\cline { 2 - 4 } & High School & 15 & 50,0 \\
\hline
\end{tabular}

According to the data presented in Table 1 , most teachers $(n=12)$ have between 5 and 10 years of teaching experience, which gives $40 \%$. Seven teachers $(23.3 \%)$ have between 2 and 4 years of teaching experience, while 5 of them (16.6\%), have between 11 and 20 years of teaching experience. The same number, namely five teachers $(16.6 \%)$ have more than 20 years of teaching experience, and only one teacher $(3.3 \%)$ has less than a year of teaching experience.

\subsection{Research data collection instrument}

The qualitative data was collected through diaries that the English teachers were asked to keep. They were instructed to divide the diaries into four sections corresponding to the negative emotions namely, anxiety, anger, and loneliness. The teachers were asked to describe the factors during online teaching, which evoked the negative emotions mentioned above. It is worth mentioning that after having delivered the completed diaries, the participants of the study expressed their gratitude, stating that this experience helped them with understanding and dealing with their negative emotions.

\subsection{Research implementation}

The research took place between September 2020 and January 2021. All the participants of the study were informed that it was anonymous and that the data collected through the diaries would be used for research purposes only. Furthermore, each teacher signed an agreement and provided the information concerning teaching experience, and the type of school in which he/she was working. Even though the participants of the study were given a choice as far as language was concerned, all the answers were provided in Polish which might be connected with the fact that it is easier to express one's emotions in L1 (Foolen, 2016; Pavlenko, 2008). Only two diaries were written in an electronic version; the others were written by hand and took the form of a notebook. Except for the two diaries delivered via email, the others were sent by traditional post. 


\section{Research results}

Due to the huge amount of data collected, the most common tendencies concerning the negative emotions identified in the responses will be provided in the following part of the article.

\section{The feeling of anxiety}

"I feel more and more anxious and stressed, which is due to the number of classes that $I$ have online. I have to sit in front of the computer all day. Apart from preparing the lessons I have to fill in lots of paperwork... I'm exhausted. For the last few days, I couldn't rest properly - just work and work"'.

"Today, I had a very bad day. I really feel anxious about my future. My contract finishes this year, and I don't know if it's going to be prolonged. I have been trying to talk to the headmaster, but she says that she doesn't know anything as the situation during the pandemic is so unstable".

"I don't know if I am doing my job properly. I haven't received any proper teaching training concerning teaching online. I'm afraid that I won't manage if it's going to last the whole semester".

"I gave my students the test and the results are terrible. I think that this online teaching doesn't make any sense... I can't see their faces, they don't respond to my questions, and the tests' results are not very good. I'm really worried about their progress. I think that some of them might not pass their matura exam".

"I don't know how to motivate my learners. I have a feeling that they are demotivated by online learning. I don't know what to do... Today when I was trying to have a nice conversation class, nearly none of them responded to my questions. I thought that I had prepared a really nice online lesson, but I'm afraid that I failed... I couldn't motivate them to be active".

"I'm afraid of failure as a teacher. I have been teaching for only 2 years, and this online teaching is something that I cannot deal with. I have a feeling that I fail every day. I can see that my students do not follow the lessons... sometimes, I even have a feeling that they are not there... maybe sleeping or doing something else. I think that I'm becoming more and more frustrated".

"I'm afraid that I am really discouraged by online teaching. I'm permanently tired. I feel stressed that I can't meet my students' expectations. When we had

\footnotetext{
All emphasis added.
} 
face-to-face classes, I was more motivated and enthusiastic; now it's gone. I think that I'm experiencing teacher's burnout syndrome".

"I'm afraid that I'm not good enough at online teaching. Before we were asked to teach online, I hardly ever used any computer or online materials. For me, the most important was the coursebook. Now I feel so frustrated... I'm sure that my students know much more, and they often laugh at me".

"As I teach in a primary school, I often have problems with discipline. I'm afraid that it is due to online education. I have a feeling that the learners respect me a little bit less. It always takes me a lot of time to encourage them to listen to what I'm going to say. I'm afraid that I can't cope with the discipline online, and I don't have the proper tools. What can I do? I'm here and they are there".

"I'm afraid that my attitude to teaching, other teachers, and learners has changed due to online education. I'm stressed all the time and cannot cope with this type of education. I'm also nervous, and sometimes I shout at my students. I know that my behaviour is not proper, but I can't control it".

When analysing the answers provided by the English teachers, there are a few factors which make them feel anxious, namely: the amount of work which online education requires, uncertainty about the future and fear about being fired, lack of proper teacher training concerning online teaching, students' lack of progress, students' lack of motivation, students' expectations which are not fulfilled, problems with discipline and a negative attitude to teaching, other teachers and learners, which might lead to teachers' burnout.

\section{The feeling of anger}

'I feel angry because I can't organize my time. Sometimes, I can't force myself to prepare for the classes, as there are so many things to do at home. What is more, I have 2 kids who also learn at home, and I often need to help them. I feel angry and frustrated because I'm constantly disrupted, and I can't concentrate on my work".

"My students made me so angry today. Last week I gave them some homework, and none of them did it. They were supposed to prepare a project about their free time activities and they didn't do it. When I was asking them why most of them didn't answer my questions, they stated that their microphones didn't work".

"One parent made me really angry yesterday. Her child never does the homework, and whenever I ask him questions, he pretends that his microphone doesn't work. I called his mother yesterday and told her about the situation. She told me 
that it was my fault because I couldn 't teach online properly. It was unbelievable. I wanted to say something and she just put down the phone".

“The current government makes me really angry. We haven't been offered any help. The lessons last 30 minutes, and we still have to follow the curriculum and cover all the topics. I really don't know how to do it".

"I am really angry because one of my students showed disrespect. I asked him to do the exercise, and he didn't do it. I was trying to find out why and he responded that while he was learning online, I couldn't do anything, and it was up to him whether he wanted to learn or not. The other students started laughing, and I totally lost control over the lesson. This situation really made me angry, and I had to get some fresh air".

"I often get angry during online classes because many students do not follow my instructions. I tell them what to do, which copy to look at, but they check something online, do not listen to me and then suddenly disappear, claiming that something happened with the Internet connection. This is really frustrating”.

"What makes me angry during online education is students' laziness. They don't do many tasks, and I simply have a feeling that it's because they are lazy. I usually don't see their faces, so they might even stay in bed during the lesson. A few days ago, one student didn't hear my questions because he was sleeping".

"Disruptions during the classes make me so angry. Sometimes the Internet is so weak that they can't hear me or I can't hear them. I can also hear a lot of noise - dogs barking, TV on, people talking etc.... All these disruptions have a negative impact on my students' concentration on the lesson".

"What makes me feel angry is the fact that I can't see my students, and therefore, I don't know if they understand what I'm saying. Non-verbal signs are crucial here. Of course, I ask them many questions in order to find out if they understand what I'm talking about, but they simply don't answer and there is silence".

"Huge amounts of work makes me angry and hours spent in front of the computer. I have to prepare lessons online and correct everything online, as well. I'm not used to sitting in front of the computer for the whole day, and I simply feel exhausted".

From the data provided by the teachers, I can see that they quite often feel anger. The most common factors that lead to the feeling of anger are problems with time management, students' laziness and disrespect, lack of parents' and govern- 
ment's cooperation, inability to see the students who have their cameras turned off, disruptions, huge amounts of work and hours spent in front of the computer.

\section{The feeling of loneliness}

"Since the beginning of online education, I have been feeling very lonely because I don't get any support from my headmaster and from other colleagues. Whatever I do, I need to do it on my own. This feeling is terrible".

"I don't know how to motivate my learners. I feel so lonely and hopeless, as all my efforts are not appreciated. My students are discouraged by online learning, and I can feel that they are also feeling frustrated".

"I try hard not to show my loneliness and negative attitude towards any kind of situation. However, to be honest, I do not like when my students ignore, cheat and are dishonest. This is really frustrating".

"When we suddenly faced the COVID-19 pandemic, I didn't know what to do. I didn't know who to turn to and when I was trying to talk to my headmaster and ask for some support, I was just ignored. I had no idea how to teach 7 and 8 years olds online! They were not listening to me and were constantly disrupted by other things."

"I have been teaching for 16 years now, and I have to say that I have never felt as lonely as I feel now. I'm closed in my room, in front of the computer, talking to the screen, not knowing if my students are there or not. I might even say that sometimes I feel stupid because I have a feeling that I'm talking to myself'.

"When I was going to school, I was always around people. Since last April I have been staying alone at home, talking to the screen and I have a feeling that I'm completely alone. I know that my personal life shouldn't have any impact on my teaching but it does. I wish I could go back to school".

"Yesterday, I just felt so lonely. I had a very problematic pupil who was misbehaving during lessons, so I decided to ask our school psychologist for help, and the response was really shocking to me as I was told that most of the students had some psychological problems because of online education, and she couldn't help everybody. She told me that I should educate myself in psychology and deal with problematic students on my own".

"I'm afraid that lack of support from parents makes me feel lonely in the whole process of online education. I have asked for help many times and hardly 
ever received any support. I know that many parents cannot cope with the situation but we should support each other; it would be much easier".

"Isolation, in general, makes me feel so lonely. I can't see my colleagues, my pupils... and what is more, I cannot see the future in bright colours. I have stopped watching the news as the numbers made me even more frustrating and had a negative impact on my teaching".

"Since the beginning of the COVID-19 pandemic, I have been working on my own preparing all the teaching materials. I have been feeling very lonely because I didn't receive any support from my colleagues. I always thought that we would support each other and do things together but unfortunately, it didn't happen even though I wrote many e-mails to them suggesting some cooperation".

Hawkley, Brown, and Cacioppo (2005, p. 800) claim that the general feeling of loneliness is likely to have various causes, including perceptions of being rejected or isolated, having inadequate emotional and instrumental social support from interpersonal interactions and friendships, and lacking a sense of connectedness within the larger community. The teachers who took part in the current research provide the following factors which had an impact on their loneliness: lack of support from headmasters, colleagues, psychologists and parents, students' lack of motivation, ignorance and dishonesty, isolation, and the feeling of being at home in front of the computer.

\section{Discussion}

Several studies indicate multiple factors that have an impact on teachers' negative emotions, such as anxiety, anger, fear and loneliness (Gavish \& Friedman, 2010; MacIntyre et al., 2019; Mailizar, Almanthari, Maulina, \& Bruce, 2020). Without any doubt, COVID-19 and the online education challenges that the teachers had to face increased these negative feelings. As revealed by several studies, teachers' negative emotions might be caused by students, teachers themselves, the process of learning and teaching, educational policies, parents' expectations and relationships with other colleagues from school (Becker et al., 2014; Scott \& Sutton, 2009; Traxler \& Frenzel, 2015).

When analysing the English teachers' responses concerning negative emotions caused by students and the process of learning, most of them describe the situations in which they feel anxious because they cannot see their students' progress and are afraid that they might not pass their final exams. They also feel stressed because they have a feeling that they failed as teachers who cannot motivate their students to learn. Additionally, they have a feeling that they do not meet their students' expectations and cannot control their behaviour. The current research results go in tandem with the research results obtained by van Uden et al., (2014, 
p. 30) who also claim that teachers' feeling of anxiety is mostly caused by students negative learning approaches. As for the situations that evoke anger, the English teachers usually mention lack of homework, disrespect, and students' laziness. Duru and Bakis (2014, p. 118) as well as Mercer and Gregersen (2020), also mention these factors, which have a negative impact on teachers' well-being. As for the feeling of loneliness, the English teachers mention students' ignorance, cheating and dishonesty. They state that this feeling is really frustrating. As mentioned by Yin et al. (2017, p. 909) the feeling of loneliness is often experienced by teachers, as the work seems to be solitary. On the other hand, the feeling of loneliness might be intensified due to the current situation of the teachers.

When analysing the answers concerning the impact of negative emotions on the teachers themselves, it can be noticed that many teachers feel anxious because of the number of classes they have to teach. They stress the fact that they often feel exhausted and worried about their future. Another important factor that causes anxiety is the lack of proper teacher training. Many participants of the study mention that they did not know what to do at the very beginning of online education, as they were not offered any training. Therefore, many fear that they are not good enough at online teaching and feel stressed about it. As Mercer and Gregersen (2020) mention, teachers' constant fear about the future, emotional labour and time constraints might lead to teacher burnout syndrome. Their fear might also be linked to anger. Many participants of the study claim that they feel angry because they cannot organise their time properly. What is more, the amount of work and hours spent in front of the computer also evoke the feeling of anger which might be linked to emotional exhaustion (Keller, Chang, Becker, Goetz, \& Frenzel, 2014, pp. 7-8). Research on teachers' and students' emotions shows that physical but also emotional exhaustion might lead to sudden outbursts of anger (Frenzel, 2014; Hagenauer \& Volet, 2014; Hargreaves, 2001; Sutton \& Wheatley, 2003). When referring to the feeling of sadness, many teachers feel sad because they have a feeling that nobody cares about them and they feel at a loss. Their feeling of sadness is also linked to the feeling of loneliness. The teachers state that they feel isolated and excluded from school life. McCarthy (2020) and Kelly et al. (2021), who conducted research among teachers during the COVID-19 pandemic, came to the same conclusion. Teachers feel lonely due to the lack of physical interaction.

Last but not least is teachers' negative emotions connected with educational policies, parents' expectations and the relationships with the headmaster and other colleagues. The participants of the current study feel anxious because they have not been provided with special training concerning online education. In their opinion, it was the responsibility of the Ministry of Education and the headmaster. Moreover, the English teachers feel angry with some parents who have high expectations and do not support the teachers. When asking for help, many parents claim that it is the teachers' responsibility to provide their kids with proper edu- 
cation and pedagogical rules. Scott and Sutton $(2009$, p. 167) claim that lack of parent support is one of the most frustrating factors for the teachers. That is why they often feel angry and stressed. When describing the feeling of sadness, many English teachers feel sad because they cannot meet their colleagues from work and therefore, they feel that there is no cooperation. Even when asking for help, many teachers say that they do not feel like cooperating because they are overwhelmed with the current situation. Mailizar et al. (2020, p. 7) state that this is a common behaviour among teachers during COVID-19, who do not get enough support from the government. They feel that their work is not appreciated enough. Finally, when describing the feeling of loneliness, the teachers also mention the lack of support from parents, headmasters, colleagues and even school psychologists. As concluded by Besser, Flett, and Zeigler-Hill, (2020, p. 18), this feeling of loneliness caused by a lack of support has often been accompanied by symptoms of anxiety, depression, and sleep disturbance.

\section{Conclusions and future implications}

The Coronavirus (COVID-19) has imposed many changes in the current system of education. All schools were suddenly closed and as a result, both teachers and students had to face challenges connected with online education.

Many members of the teaching profession experienced psychological discomfort. The current study reports the negative emotions that the English teachers experienced during online education. The qualitative data shows that the teachers' negative emotions are related to students, teachers themselves, parents, headmasters, colleagues and the government. Furthermore, the findings indicate that special attention should be given to the problem of teachers' negative emotions, as they often report to be totally left on their own. Therefore, it is crucial to take care of the teachers' well-being, which has an enormous impact on the quality of education. It is essential to remember that the education received by young people in this current time of crisis will shape the society of the future.

\section{Limitations of the study}

The interpretation of the above-presented findings is limited by certain methodological constraints connected with selecting and using the research instrument. The study was mainly based on diaries, which did not contribute to its reliability. A recommendable direction for future studies could be the adoption of a mixedmethods approach enabling a combination of quantitative and qualitative tools that would lead to a cross-verification of the obtained results, thus allowing potential researchers to look at the teachers' emotions from a wider perspective.

Finally, it has to be mentioned that the limitation of the present research is also connected with the number and the profile of the study participants. The sample 
might not be representative as there were only 30 English teachers who took part in the research. It would be advisable to investigate more teachers specializing in various fields. Despite these limitations, the results of this study open up a series of possibilities for future research.

\section{References}

Al Lily A. E., Ismail A. F., Abunasser F. M., \& Alhajhoj, R. H. (2020). Distance education as a response to pandemics: Coronavirus and Arab culture. Technol. Soc. 63(101317). DOI: 10.1016/j. techsoc.2020.101317.

Arnold, J. (2019). The Importance of Affect in Language Learning. Neofilolog, 52(1), 11-14.

Becker, E. S., Goetz, T., Morger, V., \& Ranellucci, J. (2014). The importance of teachers' emotions and instructional behavior for their students' emotions - An experience sampling analysis. Teaching and Teacher Education, 43, 15-26.

Besser, A., Flett, G. L., \& Zeigler-Hill, V. (2020). Adaptability to a sudden transition to online learning during the COVID-19 pandemic: understanding the challenges for students. Scholarship of Teaching and Learning in Psychology. DOI: 10.1037/st10000198.

Brigido, M., Borrachero, A. B., Bermejo, M. L., \& Mellado, V. (2013). Prospective primary teachers' self-efficacy and emotions in science teaching. European Journal of Teacher Education, 36(2), 200-217.

Brown, C. (2017). Advantages and disadvantages of distance learning. Retrieved January 7, 2021, from https://www.eztalks.com/elearning/advantages-and-disadvantages-of-distance-learning.html.

Chen, E., Kaczmarek, K., \& Ohyama, H. (2020). Student perceptions of distance learning strategies during COVID-19. J. Dent. Edu., 1-2.

Chen, J. (2016). Understanding teacher emotions: The development of a teacher emotion inventory. Teaching and Teacher Education, 55, 68-77.

Costley, J., \& Lange, C. H. (2017). Video lectures in e-learning: effects of viewership and media diversity on learning, satisfaction, engagement, interest, and future behavioral intention. Interactive Technology and Smart Education, 14(1), 14-30.

Cuervo-Cazurra, A., Ciravegna, L., Melgarejo, M., \& Lopez, L. (2018). Home country uncertainty and the internationalization-performance relationship: Buildingan uncertainty management capability. Journal of World Business, 53 (2), 209-221.

Dumford, A. D., \& A. L. Miller. (2018). Online Learning in Higher Education: Exploring Advantages for Engagement. Journal of Computing in Higher Education, 30(3), 452-465.

Duru, E., \& Bakis M. (2014). The Roles of Academic Procrastination Tendency on the Relationships among Self-Doubt, Self Esteem and Academic Achievement. Education and Science, 23(112), $113-121$.

Flores, M. A., \& Gago, M. (2020). Teacher education in times of COVID-19 pandemic in Portugal: national, institutional and pedagogical responses. Journal of Education for Teaching: International Research and Pedagogy, 46(1), 1-10.

Foolen, A. (2016). Expressives. In N. Riemer (Ed.), The Routledge handbook of semantics (pp. 473490). Abingdon: Routledge.

Frenzel, A. C. (2014). Teacher emotions. In R. Pekrun, \& L. Linnenbrink-Garcia (Eds.), Educational psychology handbook series. International handbook of emotions in education (pp. 494-518) London: Routledge, Taylor \& Francis Group.

Gavish, B., \& Friedman I. A. (2010) Novice Teachers' Experience of Teaching: A Dynamic Aspect of Burnout. Social Psychology of Education, 13(2), 141-167. 
Hagenauer, G., \& Volet, S. E. (2014). "I don't think I could, you know, just teach without any emotion": Exploring the nature and origin of university teachers' emotions. Research Papers in Education, 29, 240-262.

Hargreaves, A. (2001). Emotional geographies of teaching. Teachers College Record, 103, 1056-1080.

Hawkley, L. C., Browne, M. W., \& Cacioppo, J. T. (2005). How can I connect with thee? Let me count the ways. Psychological Science, 16, 798-804.

Hutt, M. (2017). Top 10 disadvantages of distance learning. Retrieved December 15, 2020, from https://www.eztalks.com/elearning/top-10-disadvantages-of-distance-learning.html.

Kaur, G. (2020). Digital Life: Boon or bane in teaching sector on COVID-19. CLIO an Annual Interdisciplinary Journal of History, 6(6), 416-427.

Keller, M. M., Chang, M.-L., Becker, E. S., Goetz, T., \& Frenzel, A. C. (2014). Teachers' emotionalexperiences and exhaustion as predictors of emotional laborin the classroom: an experience sampling study. Front. Psychol., 5, 1442. DOI: 10.3389/fpsyg.2014.01442.

Kelly, K., Zakrajsek, T., \& Pacansky-Brock, M. (2021). Advancing Online Teaching. Creating EquityBased Digital Learning Environments. Virginia: Stylus Publishing, LLC.

Kim, L., \& Asbury, K. (2020). "Like a rug had been pulled from under you": The impact of COVID-19 on teachers in England during the first six weeks of the UK lockdown. British Journal of Educational Psychology, 1-22.

Kitching, K. (2009). Teachers' negative experiences and expressions of emotion: Being true to yourself or keeping you in your place? Irish Educational Studies, 28(2), 141-154.

Krish, P. (2008). Language Learning in the Virtual World: Instructors' Voices. International Journal of Pedagogies and Learning, 4(4), 13-129.

Kruse, K. (2001). The benefits and drawbacks of e-learning. Retrieved November 2, 2020, from http:// www.e-learningguru.com/articles/art1_3.htm.

Lier, L. van (1988). The Classroom and the Language Learner. London: Longman.

MacIntyre, P., Ross, J., Talbot, K., Mercer, S., Gregersen, T., \& Banga, C.-A. (2019). Stressors, personality and wellbeing among language teachers. System, 82, 26-38.

MacIntyre, P., Gregersen, T., and Mercer, S. (2020). Language teachers' coping strategies during the Covid-19 conversion to online teaching: Correlations with stress, wellbeing and negative emotions. System, 94, 1-13.

Mailizar, Almanthari, A., Maulina, S., \& Bruce, S. (2020). Secondary school mathematics teachers' views on E-learning implementation barriers during the COVID-19 pandemic: The case of Indonesia. EURASIA Journal of Mathematics, Science and Technology Education, 16(7). DOI: 10.29333/ejmste/8240.

Manzoor, A. (2020). Online Teaching and Challenges of COVID-19 for Inclusion of Persons with Disabilities in Higher Education. Retrieved December 12, 2020, from https://dailytimes.com.pk/ 595888/online-teaching-and-challenges-of-covid-19-for-inclusion-of-pwds-in-higher-education/.

McCarthy, K. (2020). The global impact of coronavirus on education. Retrieved May 10, 2021, from https://abcnews.go.com/International/global-impact-coronaviruseducation/story.

Mercer, S., \& Gregersen, T. (2020). Teacher Wellbeing. Oxford: Oxford University Press.

Miller, T. (2020). Online Learning: Practices, Perceptions, and Technology. Canadian Journal of Learning and Technology, 46(1). DOI:10.21432/cjlt27894.

Nagrale, P. (2013). Advantages and disadvantages of distance education. Retrieved October 22, 2020, from https://surejob.in/advantages-anddisadvantages-of-distance-education.html.

Neville, B. (2013). The enchanted loom. In M. Newberry, A. Gallant, \& P. Riley (Eds.), Emotion and school: Understanding how the hidden curriculum influences relationships, leadership, teaching and learning (pp. 3-23). Bingley: Emerald.

Pavlenko, A. (2008). Emotion and emotion-laden words in the bilingual lexicon. Bilingualism: Language and Cognition, 11(2), 147-164. 
Prado-Gascó, V., Gómez-Domínguez M. T., Soto-Rubio A., Díaz-Rodríguez L., \& Navarro-Mateu, D. (2020). Stay at Home and Teach: A Comparative Study of Psychosocial Risks Between Spain and Mexico During the Pandemic. Front. Psychol. 11:566900. DOI: 10.3389/fpsyg.2020.566900.

Rapanta, C., Botturi, L., Goodyear, P., Guàrdia, L., \& Koole, M. (2020). Online university teaching during and after the Covid-19 crisis: Refocusing teacher presence and learning activity. Postdigital Science and Education, 1-23. Retrieved April 12, 2021, from https://www.ncbi.nlm.nih.gov/ pmc/articles/PMC7339092/.

Saunders, R. (2013). The role of teacher emotions in change: Experiences, patterns and implications for professional development. Journal of Education Change, 14, 303-333.

Scott, C., \& Sutton, R. (2009). Emotions and change during professional development for teachers: A mixed methods study. Journal of Mixed Methods Research, 3(2), 151-17.

Stanley, C. (1999) Learning to think, feel and teach reflectively. In J. Arnold (Ed.), Affect in language learning, 109-124. Cambridge: Cambridge University Press.

Sutton, R. E., \& Wheatley, K. F. (2003). Teachers' emotions and teaching: A review of the literature and directions for future research. Educational Psychology Review, 15, 327-358.

Swan, E., \& Bailey, A. (2004). Thinking with feeling: The emotions of reflection. In M. Reynolds, \& R. Vince (Eds.), Organizing reflection (pp. 105-125). Aldershot: Ashgate.

Traxler, J. (2018). Distance Learning - Predictions and Possibilities. Education Sciences, 8(1), 13-35.

Traxler, J. L., \& Frenzel, A. (2015). Facets of teachers' emotional lives: A quantitative investigation of teachers' genuine, faked, and hidden emotions. Teaching and Teacher Education, 49, 78-88.

Taylor, E.W. (2001) Transformative learning theory: A neurobiological perspective of the role of emotions and unconscious ways of knowing. International Journal of Lifelong Education, 20(3), 218-236.

Tuominen S., \& Leponiemi, L. (2020). A learning experience for us all. Spotlight: Quality education for all during Covid-19 crisis. OECD/Hundred Research Report \#011. Retrieved May 1, 2020, from https://hundredcdn.s3.amazonaws.com/uploads/report/file/15/hundred_spotlight_ covid-19_digital.pdf.

United Nations Educational, Scientific and Cultural Organization (UNESCO) (2020). Adverse effects of school closures, 2020. Paris: UNESCO.

Uden, J. M. van, Ritzen, H., \& Pieters, J. M. (2014). Engaging students: The role of teacher beliefs and interpersonal teacher behavior in fostering student engagement in vocational education. Teaching and Teacher Education, 37, 21-32.

Watson, D., \& Clark, L. A. (1988). Development and validation of brief measures of positive and negative affect: The PANAS Scales. Journal of Personality and Social Psychology, 54, 1063-1070.

Weiss, R. P. (2000). Emotion and learning. Training and Development, 54(11), $44-48$.

Yao, X., Yao, M., Zong, X., Li, Y., Li, X., Guo, F., \& Cui, G. (2015). How school climate influences teachers' emotional exhaustion: The mediating role of emotional labor. International Journal Environmental Research and Public Health, 12, 12505-12517.

Yin, H. B., Huang, S., \& Wang, W. (2017). Work environment characteristics and teacher well-being: The mediation of emotion regulation strategies. International Journal of Environment Research Public Health, 13(12), 907-923.

Yoo, J., \& Carter, D. (2017). Teacher Emotion and Learning as Praxis: Professional Development that Matters. Australian Journal of Teacher Education, 42(3), 37-52.

Zembylas, M., Charalambous, C., \& Charalambous, P. (2014). The schooling of emotion and memory: Analyzing emotional styles in the context of a teacher's pedagogical practices. Teaching and Teacher Education, 44, 69-80. 